\title{
Ingenious method of external fixator use to maintain alignment for nailing a proximal tibial shaft fracture
}

\author{
Prateek Behera, M.D., ${ }^{1}$ Sameer Aggarwal, M.D., ${ }^{1}$ Vishal Kumar, M.D., ${ }^{1}$ \\ Umesh Kumar Meena, M.D., ${ }^{2}$ Balaji Saibaba, M.D. ${ }^{1}$
}

1'Department of Orthopedics, PGIMER, Chandigarh, India

${ }^{2}$ Department of Orthopedics, SMS Medical College, Jaipur, Rajasthan, India

\begin{abstract}
Fractures of the tibia are one of the most commonly seen orthopedic injuries. Most of them result from a high velocity trauma. While intramedullary nailing of tibial diaphyseal fractures is considered as the golden standard form of treatment for such cases, many metaphyseal and metaphyseal-diaphyseal junction fractures can also be managed by nailing. Maintenance of alignment of such fractures during surgical procedure is often challenging as the pull of patellar tendon tends to extend the proximal fragment as soon as one flexes the knee for the surgical procedure. Numerous technical modifications have been described in the literature for successfully nailing such fractures including semi extended nailing, use of medial plates and external fixators among others. In this study, it was aimed to report two cases in which we used our ingenious method of applying external fixator for maintaining alignment of the fracture and aiding in the entire process of closed intramedullary nailing of metaphyseal tibial fractures by the conventional method. We were able to get good alignment during and after the closed surgery as observed on post-operative radiographs and believe that further evaluation of this technique may be of help to surgeons who want to avoid other techniques.
\end{abstract}

Keywords: Alignment; external fixator; intramedullary nailing; metaphyseal fractures; reduction; tibia fractures.

\section{INTRODUCTION}

Tibia is the most commonly fractured long bone of the human body. ${ }^{[I]}$ Intramedullary nailing has been considered as the gold standard surgical treatment for tibial diaphyseal fractures. ${ }^{[2,3]}$ Intramedullary nailing, as a treatment method for the proximal metaphyseal tibia fractures, has unsolved controversies associated with it. While nailing of the proximal metaphyseal fractures allows the procedure to be carried out in a closed manner, a high complication rate has been mentioned in the literature especially due to unsuccessful reduction and malalignment. ${ }^{[4,5]}$ Numerous modifications of the standard technique of intramedullary nailing have been proposed by researchers to overcome these problems. These include the use of blocking screws, small plate before nailing, using an

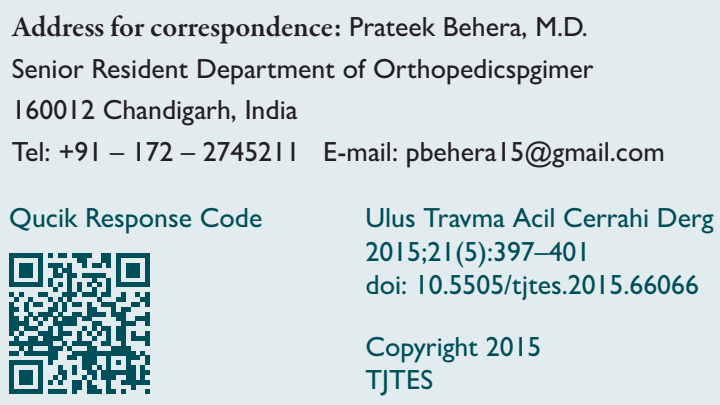

external fixator, nailing in semi extended position, and retropatellar or parapatellar approach for nailing. ${ }^{[6-\mid I]}$ Beside other techniques, we aimed to describe a new, easy, and reproducible technique for difficult tibia proximal diaphysis fractures. Here, we described an ingenious method of intrameduallry nailing of proximal tibial fractures using the ubiquitously available external fixators for maintain the reduction and alignment of the fracture. We used the same in two patients who had closed fractures of the tibia in the proximal metaphyseal area.

\section{CASE REPORT}

A 46-year-old male patient involved in a traffic accident while riding a motorbike presented with closed fracture of the metaphyseal part of the left tibia. The distal pulses were palpable and there were no neurological deficits. The injured limb was immobilized in a splint and elevated. There was no articular involvement and a decision of closed intra-medullary nailing was taken. The second case was a 35-year-old female who had also fractured the right tibia after being involved in a traffic accident. The injury pattern was similar to that of the first patient and intramedullary nailing was planned.

Both patients were operated under combined spinal and epidural anesthesia on a standard radiolucent operating table 


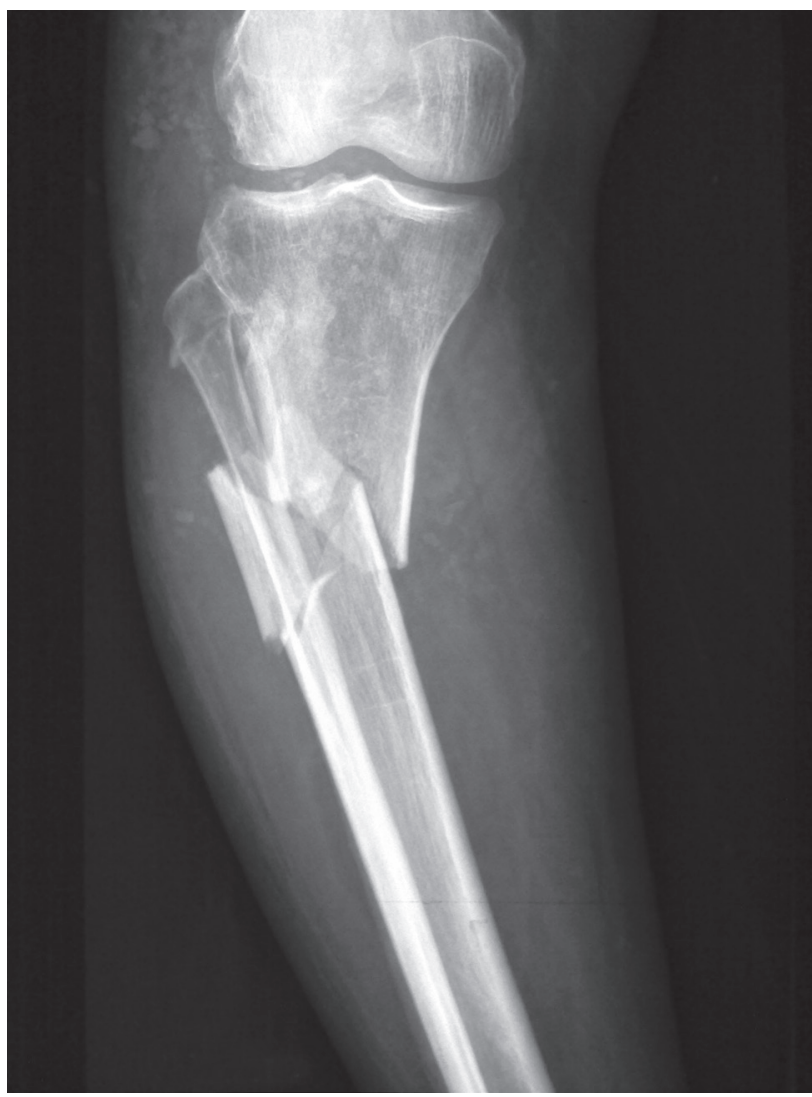

Figure 1. Anteroposterior radiograph showing a fracture of proximal tibial shaft with comminution.

in supine position. After prepping and draping the limb, the whole limb was imaged once with image intensifier. The location of the fracture (Fig. I) was noted. A point $\mathrm{I}-\mathrm{I} .5 \mathrm{~cm}$ away from the fracture on the proximal and distal fragment was marked (Figs. 2a-c). A $4.5 \mathrm{~mm}$ Schanz screw was passed at the point marked on the proximal fragment from the medial side of the tibia towards the lateral side such that it was located at the junction of anterior two third and posterior one third of the width of the tibia. This Schanz screw was almost horizontal to the ground. A second Schanz screw was placed from lateral to medial at a similar location in the proximal fragment. The positions of these were verified under image intensifier.

Afterwards, $4.5 \mathrm{~mm}$ cortical Schanz screws were placed around $\mathrm{I} \mathrm{cm}$ away in the distal fragment. Under image intensification, the fracture was reduced and the alignment was maintained and held in place by attaching the Schanz screws on either side of the fracture with tubular rods). Thus, we obtained a uniplanar bilateral external fixator configuration stabilizing the fracture. After this, a tubular rod was placed transversely connecting the two Schanz screws on the proximal fragment, and then, was pushed down to the maximum extent flush to the leg and tightened in position (Figs 3a-c).

The knee was then flexed to ninety degrees and a midline incision was made just as done in simple diaphyseal fractures of tibia during standard nailing. The patellar tendon was split in the middle and entry point was made lateral to the medial tibial spine on the antero-posterior view. On lateral view, it corresponded to the extra-articular part of the tibia. With the transverse tubular rod in place, we carried out reamed intramedullary nailing of the two tibial fractures and the locking was done distally with two screws and proximally with multiple screws including two medio-lateral, two oblique and one AP screws. After this, the external fixator frame was removed completely, and the operated leg was placed through a full range of motion to look for fracture stability. In addition, varus and valgus stress forces were applied at the fracture site, and the stability of the fracture was evaluated under image intensifier. Radiographs obtained postoperatively show adequate reduction and acceptable alignment of the fracture in both the antero posterior and lateral views, though some malalignment is visible in the lateral view (Figs $4 a$ and b).
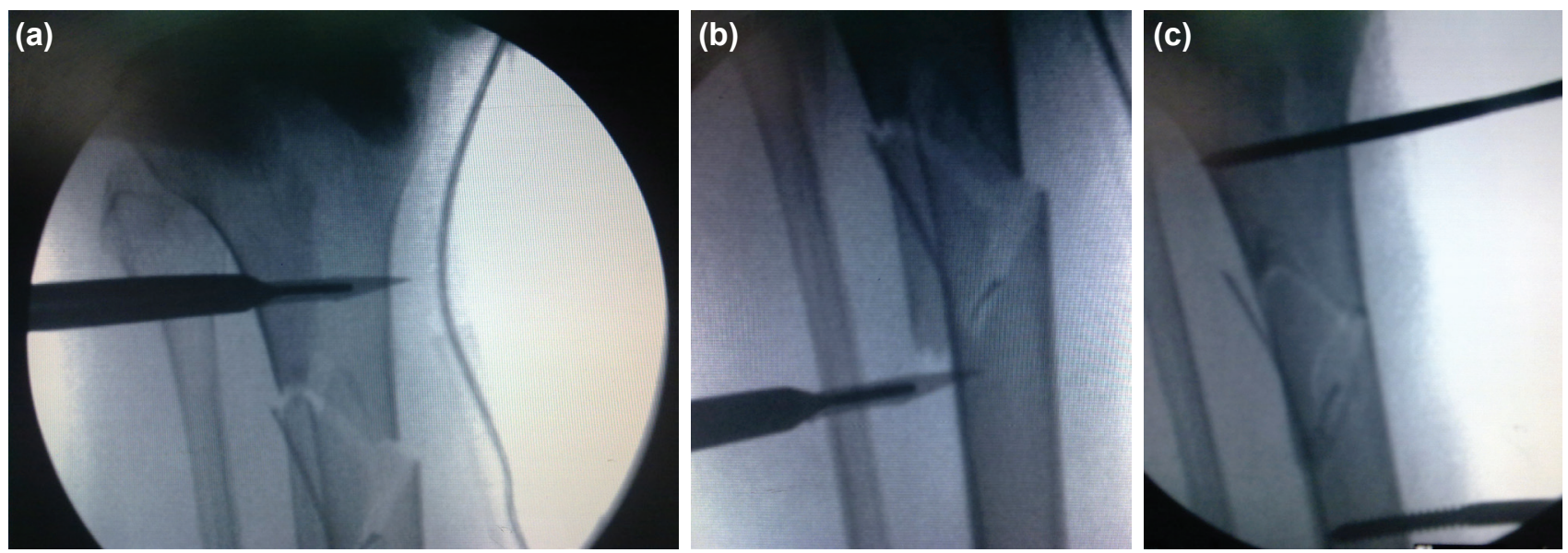

Figure 2. (a) Image of the image intensifier showing the identification of Schanz screw insertion site on the proximal fracture fragment with a knife. (b) Image of the image intensifier showing the identification of Schanz screw insertion site on the distal fracture fragment with a knife. (c) Image of the image intensifier after placement of one Schanz screw each in the proximal and distal fragment. Second set of Schanz screws is yet to be placed. 

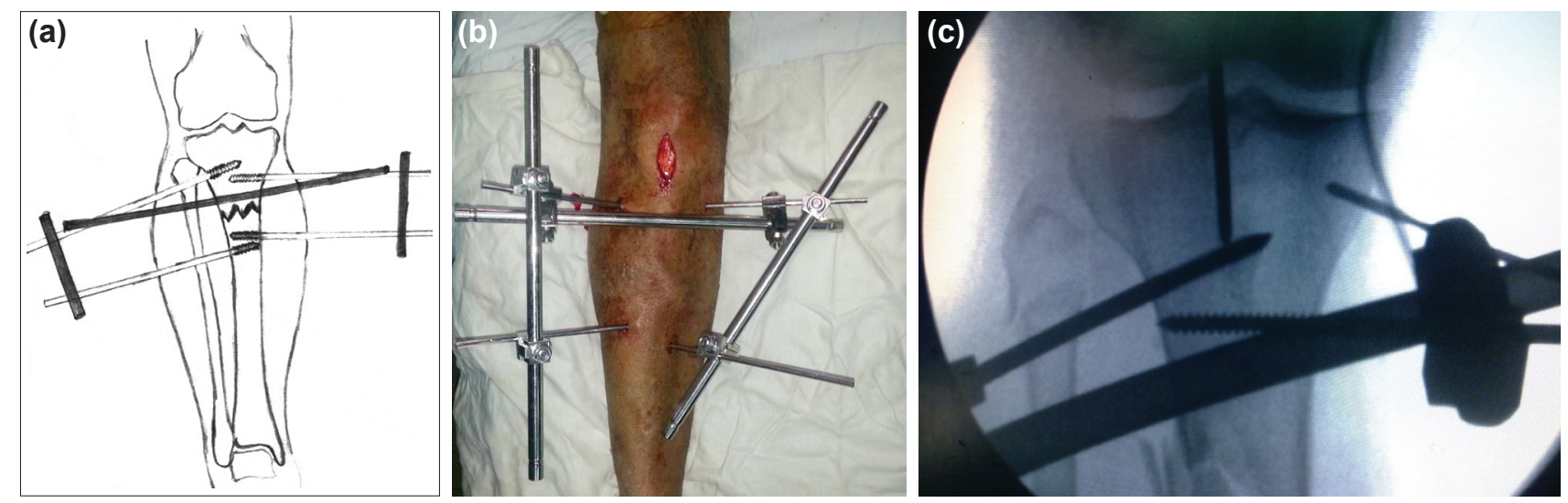

Figure 3. (a) Appearance of the construct after all Schanz screws were applied. Solid black lines represent the connecting rods. (b) The final construct of the external fixator used for achieving reduction along with the mid line skin incision is shown in this figure. (c) The image intensifier showing the proximal part of the construct and the direction of entry marked by a thick Kirschner wire.

Both patients were allowed to sit up from the next day onwards and were started on knee range of motion and quadriceps exercises. Non-weight bearing axillary crutch walking was also allowed.

\section{DISCUSSION}

Intra medullary nailing of a bone tends to follow all the principles of fracture fixation enumerated by the $A O$ group. It offers mechanical and biological advantages over other fixation methods. ${ }^{\left[{ }^{[2]}\right]}$ Preservation of the soft tissues around the tibia tends to promote the rate of union of the bone. Nailing of fractures in the proximal part of the tibial shaft and the proximal tibial metaphysis is often not a simple and straight forward procedure. This is due to the inherent geometry of the proximal tibia and also because of the surgical technique most commonly used for tibia nailing.

The wide proximal metaphyseal area of the tibia permits the toggle of a nail both in the medio-lateral plane and also in the antero-posterior plane, thus leading to a varus or valgus at the fracture site, and hence, may lead to malalignment of the fracture. ${ }^{[7,12]}$ Moreover, the standard technique of nailing involves flexing of the knee to ninety degrees for almost every step of the procedure; with an intact extensor mechanism, there is a forward and upward force on the proximal fragment which tends to pull it into extension and creates an anterior angulation at the fracture site. ${ }^{[I]}$ Moreover, making the entry point medially may direct the nail laterally, and thus, create a valgus deformity. ${ }^{[1]}$
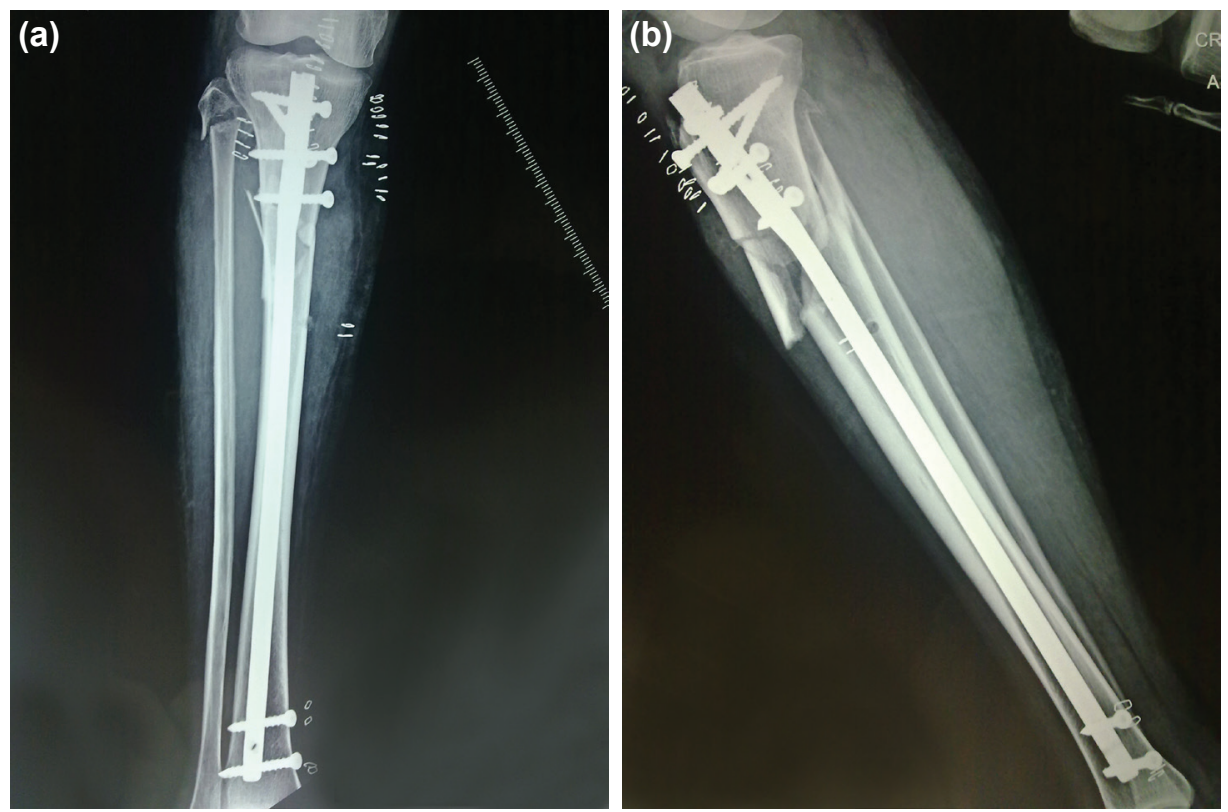

Figure 4. (a) Anteroposterior radiograph showing good alignment and reduction after surgery. (b) Lateral radiograph showing the reduction and alignment after the procedure, though some residual anterior angulation is still present. 
The techniques described for avoiding these problems have been numerous including the blocking or poller screws which are placed to decrease the overall diameter of the medullary canal, and thus, decreasing the space available for toggle of the nail. ${ }^{[6,7]}$ The semi extended nailing technique of Tornetta et al. is also helpful in many cases by decreasing the quadriceps pull, and hence, preventing the anterior angulation. ${ }^{[1]}$ Use of a small plate to reduce the fracture has also been described, but this may not be useful in every case as the local skin condition and swelling may not allow the application of a plate. All these methods are useful in different situations and available studies also support good outcomes by their use. ${ }^{[13]}$ Semi extended nailing and suprapatellar portal nailing are upcoming techniques and an orthopedic surgeon may not be well versed with them. Moreover, using supra patellar portal nailing technique may be technically demanding to the untrained, and in such situations, may lead to patellar and tibial articular cartilage damage and may increase the probability of knee joint infection. In this regard, knowledge of a simple modification of the conventional nailing technique might be beneficial for an orthopedic surgeon. Use of a small plate applied medially to achieve reduction while the fracture is being nailed has also been described, but this technique has some limitations as it is difficult to be used when there is medial comminution and it significantly increases surgery time. Here, we described a modified method using simple implants (external fixator) for nailing such proximal tibial metaphyseal fractures.

The strategically placed SSchanz screws serve to act as poller screws decreasing the width of the metaphyseal part of the proximal tibia. The transversely placed tubular rod, which is placed as much lower down as possible and in contact with the proximal fragment of the tibia tended to prevent the quadriceps pull on the fragment even when we flexed the knee for nailing, and thus, prevented the anterior angulation of the proximal fragment. We made the entry point somewhat laterally, thus preventing the possibility of a valgus angulation. The nail we used had multiple proximal locking screw options and we were able to put screws in medio-lateral, oblique and anteroposterior direction. This allowed the proximal fragment to be fixed in the proper alignment and stay so even after the aligning external fixator was removed. Thus, by using our method, we were able to nail the tibia by the standard technique with good reduction and alignment. Using Schanz screws and tubular rods is also cost effective as they can be re-used after proper cleaning and sterilization.

There are certainly limitations of our method. It tends to increase the operative time as one has to properly place the Schanz screws, and also, radiation exposure is increased as a number of extra shots need to be taken for ascertaining proper screw placement.

In conclusion, we presented an ingenious way to solve the problem of aligning the proximal fragment during nailing of proximal tibia metaphyseal fractures and to maintain the reduction during the surgery. This technique needs further validation by being implemented on a greater number of patients and by being used by a greater number of surgeons. In addition, a comparison of this method with the established methods of fracture fixation in such cases is needed to evaluate its actual usefulness.

\section{Acknowledgement}

The authors are thankful to the two patients who provided their informed consent for the surgical procedure and for allowing us to publish their details.

\section{Conflict of interest: None declared.}

\section{REFERENCES}

1. Whittle AP. Fractures of the lower extremity. In: Canale ST, Beaty JH, editors. Campbell's Operative Orthopedics. 11th ed. Philadelhia: Mosby Elsevier; 2008, p. 3085-236. CrossRef

2. Schmidt AH, Finkemeier CG, Tornetta P 3rd. Treatment of closed tibial fractures. Instr Course Lect 2003;52:607-22.

3. Burç H, Dursun M, Orhun H, Gürkan V, Bayhan I. Treatment of adult tibial diaphysis fractures with reamed and locked intramedullary nailing. [Article in Turkish] Acta Orthop Traumatol Turc 2009;43:7-13. CrossRef

4. Nork SE, Barei DP, Schildhauer TA, Agel J, Holt SK, Schrick JL, et al. Intramedullary nailing of proximal quarter tibial fractures. J Orthop Trauma 2006;20:523-8. CrossRef

5. Lembcke $\mathrm{O}$, Rüter $\mathrm{A}, \mathrm{Beck} \mathrm{A}$. The nail-insertion point in unreamed tibial nailing and its influence on the axial malalignment in proximal tibial fractures. Arch Orthop Trauma Surg 2001;121:197-200. CrossRef

6. Ricci WM, O'Boyle M, Borrelli J, Bellabarba C, Sanders R. Fractures of the proximal third of the tibial shaft treated with intramedullary nails and blocking screws. J Orthop Trauma 2001;15:264-70. CrossRef

7. Krettek C, Miclau T, Schandelmaier P, Stephan C, Möhlmann U, Tscherne H. The mechanical effect of blocking screws ("Poller screws") in stabilizing tibia fractures with short proximal or distal fragments after insertion of small-diameter intramedullary nails. J Orthop Trauma 1999;13:550-3. CrossRef

8. Matthews DE, McGuire R, Freeland AE. Anterior unicortical buttress plating in conjunction with an unreamed interlocking intramedullary nail for treatment of very proximal tibial diaphyseal fractures. Orthopedics 1997;20:647-8.

9. Kubiak EN, Widmer BJ, Horwitz DS. Extra-articular technique for semiextended tibial nailing. J Orthop Trauma 2010;24:704-8. CrossRef

10. Eastman J, Tseng S, Lo E, Li CS, Yoo B, Lee M. Retropatellar technique for intramedullary nailing of proximal tibia fractures: a cadaveric assessment. J Orthop Trauma 2010;24:672-6. CrossRef

11. Tornetta P 3rd, Collins E. Semiextended position of intramedullary nailing of the proximal tibia. Clin Orthop Relat Res 1996;328:185-9. CrossRef

12. Kim KC, Lee JK, Hwang DS, Yang JY, Kim YM. Provisional unicortical plating with reamed intramedullary nailing in segmental tibial fractures involving the high proximal metaphysis. Orthopedics 2007;30:189-92.

13. Sanders RW, DiPasquale TG, Jordan CJ, Arrington JA, Sagi HC. Semiextended intramedullary nailing of the tibia using a suprapatellar approach: radiographic results and clinical outcomes at a minimum of 12 months follow-up. J Orthop Trauma 2014;28 Suppl 8:29-39. CrossRef 
OLGU SUNUMU - ÖZET

\section{Bir proksimal tibia gövde kırı̆̆ını çiviyle tespit için yaratıcı bir eksternal fiksatör kullanım yöntemi}

\section{Dr. Prateek Behera, ${ }^{1}$ Dr. Sameer Aggarwal, ${ }^{1}$ Dr. Vishal Kumar, ${ }^{1}$ Dr. Umesh Kumar Meena, ${ }^{2}$ Dr. Balaji Saibaba ${ }^{1}$}

${ }^{1}$ PGIMER Ortopedi Bölümü, Chandigarh, India

${ }^{2}$ SMS Medikal Kolej, Ortopedi Bölümü, Jaipur, Rajasthan, India

Tibia kırıkları ortopedik yaralanmalar içinde en sık görülen kırıklardan biridir. Çoğu yüksek ivmeli travma sonucu oluşmaktadır. Tibia diyafiz kırıklarında intramedüller çivileme bu olgularda altın standart tedavi olarak kabul edilse bile bu çiviyle tespit yöntemiyle birçok metafiz ve metafiz-diyafiz bileşke kırıkları da tedavi edilebilmektedir. Cerrahi işlem sırasında bu kırıklarda hizalanmanın sağlanması, patella tendonundaki çekilme, cerrahi işiem için diz fleksiyona getirilir getirilmez proksimal fragmanı uzatma eğiliminde olduğundan sıkıkla zordur. Literatürde bu kırıkların çivilemeyle başarıı tespit edilmesi için diğer yöntemler arasında yarı-uzatılmış çivileme, iç yan plakların ve eksternal fiksatörün kullanılması gibi sayısız teknik modifikasyon tanımlanmıştır. Bu yazıda, kırığın hizalanmasını sağlamak için yaratıı bir eksternal fiksatör uyguladığımız ve tibia metafız kırıklarının konvansiyonel kapalı yöntemle intramedüller çiviyle tespitine tüm süreç boyunca devam edilen iki olgu sunuldu. Kapalı cerrahi sırasında ve sonrasında ameliyat sonrası radyografilerde gözlendiği gibi iyi bir hizalama sağladık. Başka teknikleri uygulamaktan kaçınmak isteyen cerrahlara yardımcı olmak için bu tekniğin ileri değerlendirmelerinin yararlı olabileceğine inanmaktayız.

Anahtar sözcükler: Eksternal fiksatör; hizalama; intramedüller çiviyle tespit, metafiz kırıkları; redüksiyon; tibia kırıkları.

Ulus Travma Acil Cerrahi Derg 2015;2I(5):397-40I doi: 10.5505/tjtes.2015.66066 